\title{
Development of Belajar Astronomi: an Astronomy Learning Application for Kids
}

\author{
Riza Miftah Muharram \\ Department of Computer Technology \\ Faculty of Information Technology \\ University of Bina Sarana Informatika \\ Jakarta, Indonesia \\ rizabsi123@gmail.com
}

\author{
Ade Surya Budiman \\ Department of Computer Technology \\ Faculty of Information Technology \\ University of Bina Sarana Informatika \\ Jakarta, Indonesia \\ ade.aum@bsi.ac.id
}

\begin{abstract}
Learning process should be an interesting process, especially for kids in elementary school. There are many methods has delivered to make the kids going fun to learn any new thing. Information and Communication Technolgy (ICT) could been involved to the learning process. ICTbased learning tools that used to help teachers and parents are developed in this research. Astronomy is one of the fields of science which is generally taught in schools as a part of natural science subject. In this study, authors developed an astronomy learning application's named Belajar Astronomi that comes as a supplement study material for elementary students. This Astronomy Learning application is designed to be a tool for students to study astronomy independently. Belajar Astronomi's application developed with the Visual Basic programming language in Microsoft Visual Studio 2010 using Waterfall methods, to make sure Its functionality and usefulness. The application is equipped with images, text, and videos that can help students to learn astronomy more easily, Its also equipped with quizzes as training materials that can help students in sharpening their knowledge in Astronomy subject.
\end{abstract}

Keywords_-astronomy; elementary school; learning application; ICT.

\section{INTRODUCTION}

To become a developed country, science development is the main thing. In the world of modern science, astronomy is an important science to learn, especially in developing countries like Indonesia. During this time, the development and progress of astronomy was only felt in developed countries because they had adequate facilities and infrastructure. With this increasingly sophisticated technology, it should be able to provide convenience to the development of a science. So that the learning process can run more easily and quickly understood by the community.

The linguistic meaning of the word "Technology" is the methods and tools that a society has developed in order to facilitate the solution of its practical problems and to provide the necessary needs for the community [1].

Science is the most important field nowadays. Human curiosity being a platform in science development in any field.

Science would become an immediate productive force, knowledge would no longer be primarily embodied in machines, but already appropriated nature that represents knowledge would be rearranged according to certain designs and programs [2].

Astronomy itself is one of the oldest sciences on earth, which is known through ancient artifacts originating from the prehistoric era. Astronomy also has several branches of science, including cosmology, astrometry, astrophysics, astrobiology, observational astronomy, to simple ones such as the preparation of calendars.

In Indonesia, astronomy has not yet developed. There are no specific subjects to study astronomy in elementary school. Astronomy is still incorporated into other natural sciences so that it has not been studied specifically and deeply. In fact, astronomy is a science that is very useful to learn. Many developed countries put forward this knowledge since elementary school age, so students have enough understanding of astronomy and space.

Some school are still resist to use computer as learning media. But time has change, kids need something new in how to learn abstract object such as astronomy. School cannot provide a laboratory in learning astronomy like biology or chemistry does. 
Schools are traditionally resistant to change, but they cannot ignore the ways in which computer technology is transforming society. Computerassisted education will allow schools to design curricula that are individualized to each student. Outside the classroom, the easy availability of information on the Internet will increase individuals' ability to educate themselves and become lifelong learners [3].

As addition to school natural science subject, Astronomy could learn in another way. Learning Astronomy with computer application would giving more fun for kids. As addition to natural science subject in elementary school, Astronomy could learned in other way. Learning Astronomy with computer application would giving more fun for kids. To stimulate kids curiosity to astronomy's object such as sun, moon, planets or galaxies, computer application could be an excellent learning tool to use whether inside and outside classroom activity.

In this study, the authors developed computer applications named "Belajar Astronomi" to help elementary school students get basic knowledge in Astronomy. By using this application, students will get a fairly clear description of the object of Astronomy. It is expected that students understand the description and basic knowledge of Astronomy.

This application has features such as: learning the solar system, planets, getting to know galaxies, recognizing Starss, astronomical dictionaries that contain astronomical terms from $\mathrm{A}$ to $\mathrm{Z}$, astronomical video features, and quiz features as learning evaluation material from basic astronomy learning applications.

\section{THEORITICAL PLATFORM}

\section{A. Computer-Based Learning}

Conventional teaching for teen students mostly doing in face to face interaction in classroom, whereas teaching method for younger student should be more flexible in time and place manner. There are several teaching methods introduce in order to stimulate learning willingness for children. Learning while playing are perhaps the most suitable method to use. Computer-based learning could be in computer games format.

Computer-based learning is a learning method that uses computers as the main media to deliver learning content or knowledge in a field of science.

In order to make computer games be more educational, many experts and game designers have done a lot to combine education and games, and they have designed and developed a large number of educational games already [4].
Game-based learning has been found to promote a positive attitude towards learning and develop memory skills, along with its potential to connect learners and help them build self-constructed learning [5].

Student might get benefited by using computer as a helping tool in their learning process. The student expected will feel more comfort with the learning process, if it were combined with playing or educational games. Teachers and parents need to watch and supervise the students to make sure, they will get full benefit from this learning method.

\section{B. Astronomy as A Science}

Astronomy is a branch of natural science that is considered as the oldest science in human history. The main task in Astronomy is to observe objects in space, such as the Sun, Moon, Planet, and Galaxies. Along with rapid technological growth, the methods and results of observations are getting better and more precise.

Helen Johstone in her presentation [6], said that "Astronomy is not an experimental science: astronomers can't get their hands on their subject matter. Everything we know about the cosmos, we know by remote sensing".

Astronomy as a science have several study branch, some of them widely studied. As mentioning below, Astronomy has many branches, i.e [7]:
1) Astronomical Instruments and Techniques.
2) Positional Astronomy, Celestial Mechanics
3) Space Research
4) Theoretical Astrophysics
5) Sun
6) Earth
7) Planetary System
8) Interstellar Matter, Nebulae
9) Radio Sources, X-Ray Sources, Cosmic Rays
10) Stellar System, Galaxy, Extragalactic Objects, Cosmology

\section{Application Software}

Software divided into seven broad category, i.e: system, application, engineering/scientific, embedded, product-line, web/mobile and artificial intelligence.

Application software which is developed in this research can be defined as stand-alone programs that solve a specific business need [8].

This application needed by the elementary student as a learning source which make them easier to learn and understand Astronomy. To meet the needs, application software must meet the needs of end users. 
Elementary students are the end user for the application which is developed in this research. The students will actually use the software.

\section{RESEARCH METHODOLOGY}

To develop the application, authors use Waterfall Development Method. Waterfall Development Method consist of five stages [9], [10]:

\section{A. Analysis or Requirement Analysis}

To analyse the application and system requirement, authors had done three methods, i.e:

\section{1) Observation.}

Authors had observed the similar application, both desktop-based and mobile-based (Android application in Playstore). From this method, authors found any positive and negative aspect if it were compared to the application developed in this research.

2) Survey through Questionnaire.

Authors made questionnaire distributed to students and teachers, to gather information what the need of the application's users in an application of computer-aided learning.

3) Literature Research.

In development stages, authors collect and study several literature related to the application. Authors got many point of view about application development from previous researches.

\section{B. Design}

In design process, the author creates a model of the application that will be develop next. Design should meet end user's needs and technical requirements. Application design in this research, mostly focus on the user interface. The user interface must be simple, colourful, easy to use and informative.

\section{Implementation}

Using Microsoft Visual Studio 2010, the application developed in Visual Basic (VB) programming.

\section{Testing}

Black Box Testing used in development process to test the whole application functions and features.

As define in reference [8], application developer could use Black Box Testing to answer the hesitation about incorrect or missing functions of application, errors in data structures or external database access, interface errors, behaviour or performance errors and the probability of error occurrence along initialization and termination process.

\section{E. Maintenance (and Deployment)}

Finally, after there are no error occurrence found along the testing stage, the application ready to deployed by the end user. Although, some revision and patch need to prepare in deployment stage.

\section{ApPliCATION DESIGN AND SPESIFICATION}

Good application need maturity in the design of the program. To assist in program design in Belajar Astronomi's application, the author uses program design specifications including input form specifications, output form specifications, VTOC, program specifications, and flowchart.

\section{A. Specification of Input Form}

1) Main Menu Form

Consist of Application Starst Menu, Solar System (Tata Surya) Menu, Galaxy (Galaksi) Menu, Stars (Bintang) Menu, Astronomy Dictionary (Kamus Astronomi) Menu, Astronomy Quiz (Kuis Astronomi) Menu, and About Us (Tentang Kami) Menu

2) Galaxy Menu (Menu Galaksi) Form Consist of Spiral Galaxy (Galaksi Spiral) Form, and Ellips Galaxy (Galaksi Elips) Form.

\section{B. Specification of Output Form}

1) Solar System (Tata Surya) Form Consist of Sun (Matahari) Form, Mercury (Merkurius) Form, Venus Form, Earth (Bumi) Form, Mars Form, Jupiter Form, Saturn (Saturnus) Form, Uranus Form, and Neptune (Neptunus) Form

2) Spiral Galaxy (Galaksi Spiral) Form Consist of Andromeda Galaxy (Galaksi) Form, Triangulum Galaxy Form, Whirlpool Galaxy (Galaksi Pusaran) Form, Sun Flower Galaxy (Galaksi Bunga Matahari) Form, Black Eye Galaxy (Galaksi Mata Hitam) Form, and Sombrero Galaxy Form.

3) Ellips Galaxy (Galaksi Ellips) Form

Consist of M49, M59, M60, M87, M105, and IC1101 Galaxy's Form.

4) Stars (Bintang) Form

Consist of What is Stars (Apa Itu Bintang) Form, Pleaiades (Gugus Bintang) Form, and Constellations (Rasi Bintang) Form

5) Astronomy Quiz (Kuis Astronomi) Form 
Consist of Solar System Quiz (Kuis Tata Surya) Form, Galaxy Quiz (Kuis Galaksi) Form, and Stars Quiz (Kuis Bintang) Form

C. Visual Table of Content (VTOC

VTOC is showing how functions of a system or modules of a program are decomposed in a tree format [11].

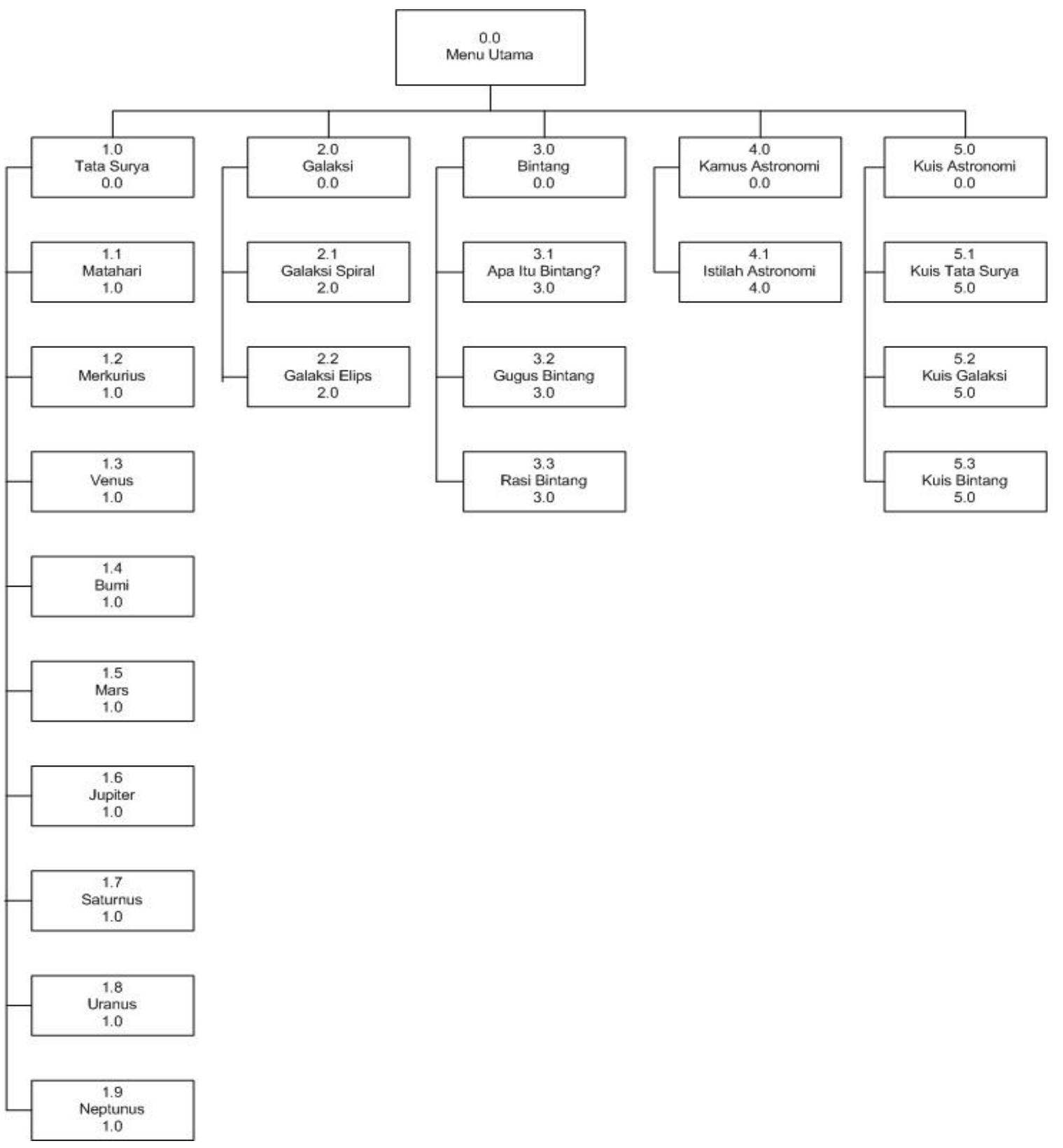

Along with the Diagram of Input-Process-Output (IPO), VTOC is one of two main component in a HIPO (Hierarchy plus Input-Process-Output) Technique, which developed by IBM's System Development Division in the late of 1970's.

Fig. 1 Visual Table of Content

\section{Specification of Program}

Consist of Main Menu, Solar System (Tata Surya), Galaxy, Stars, Astronomy Dictionary, and Astronomy Quiz

\section{E. Flowchart}

There are several Flow Chart designed for the application, i.e:

\section{1) Main Menu Flowchart}


Chart shown in Fig. 2, to describe flowing process from the Starst of the application to the Main Menu choices, that consist of Tata Surya, Galaksi, Bintang, Kamus Astronomi, and Kuis Astronomi.

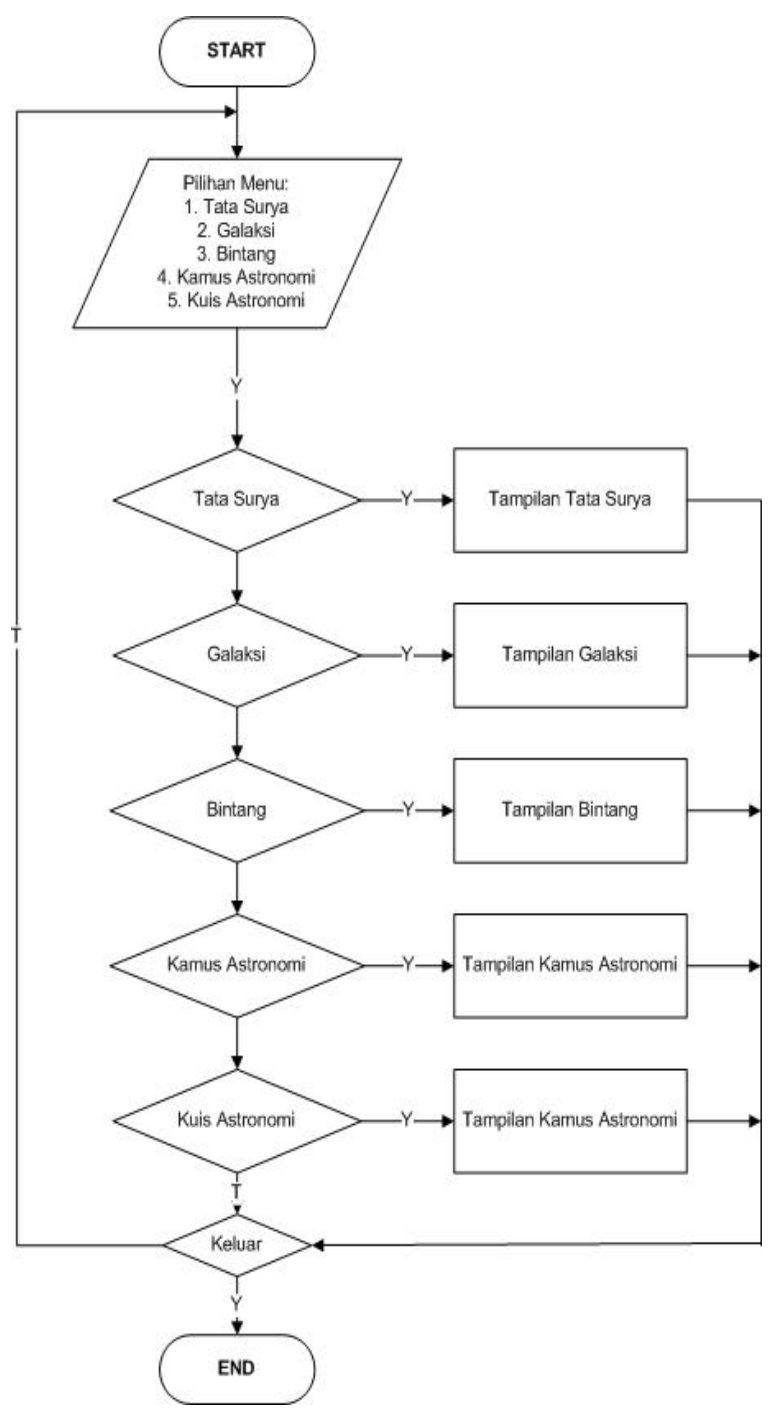

Fig. 2 Main Menu Flowchart

2) Solar System Flow Chart

Chart shown in Fig. 3, to describe flowing process in the Solar Sytem (Tata Surya) Menu choices, that consist of Matahari, Merkurius, Venus, Bumi, Mars, Jupiter, Saturnus, Uranus and Neptunus.

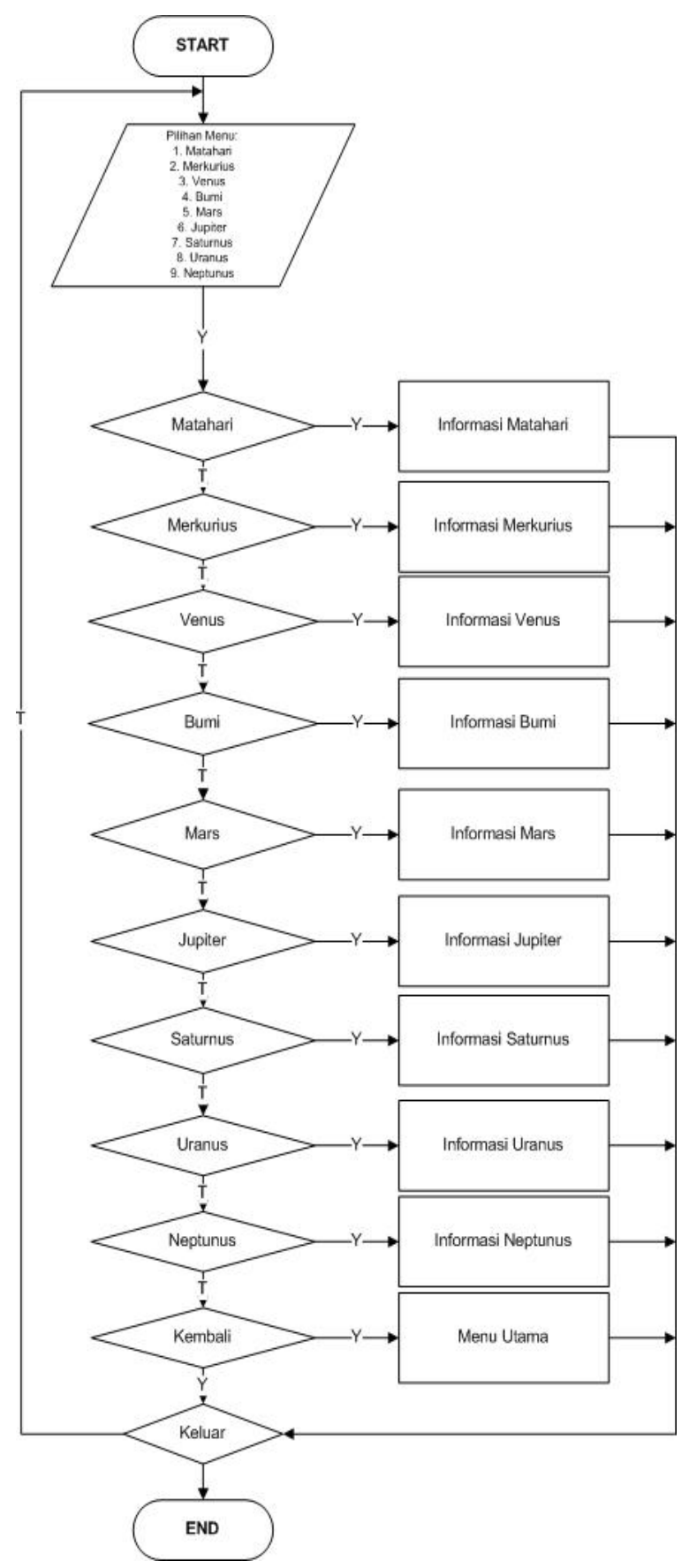

Fig. 3 Solar System Flow Chart

3) Galaxy Flow Chart

Chart shown in Fig. 4, to describe flowing process in the Galaxy Menu, that consist of Galaksi Spiral and Galaksi Ellips. 


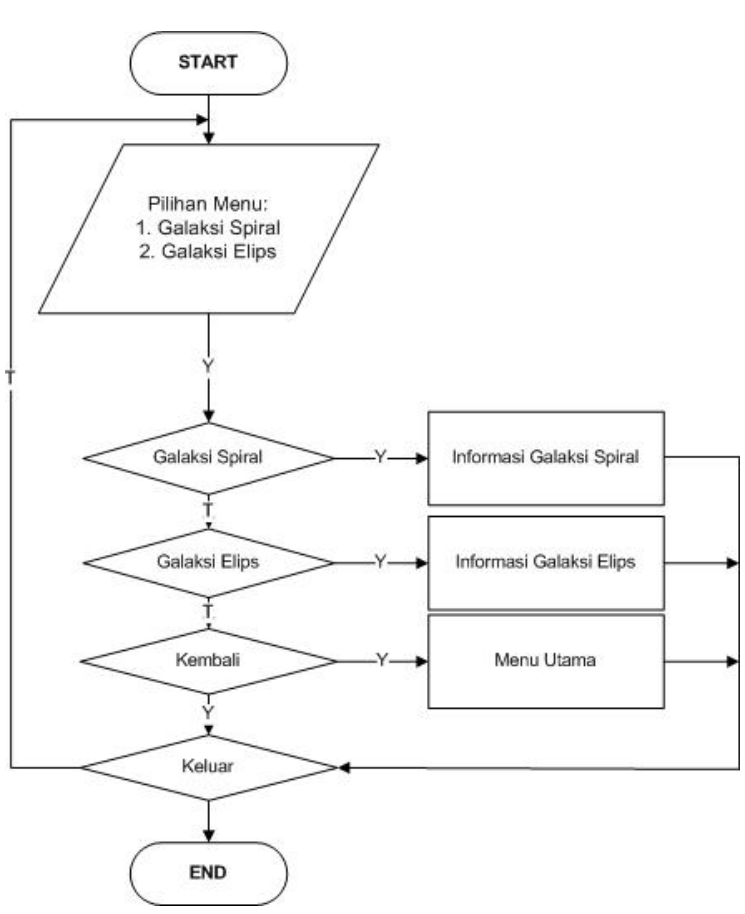

Fig. 4 Galaxy Flow Chart

4) Stars Flow Chart

Chart shown in Fig. 5, to describe flowing process in the Stars Menu, that consist of Apa itu Bintang, Gugus Bintang, and Rasi Bintang

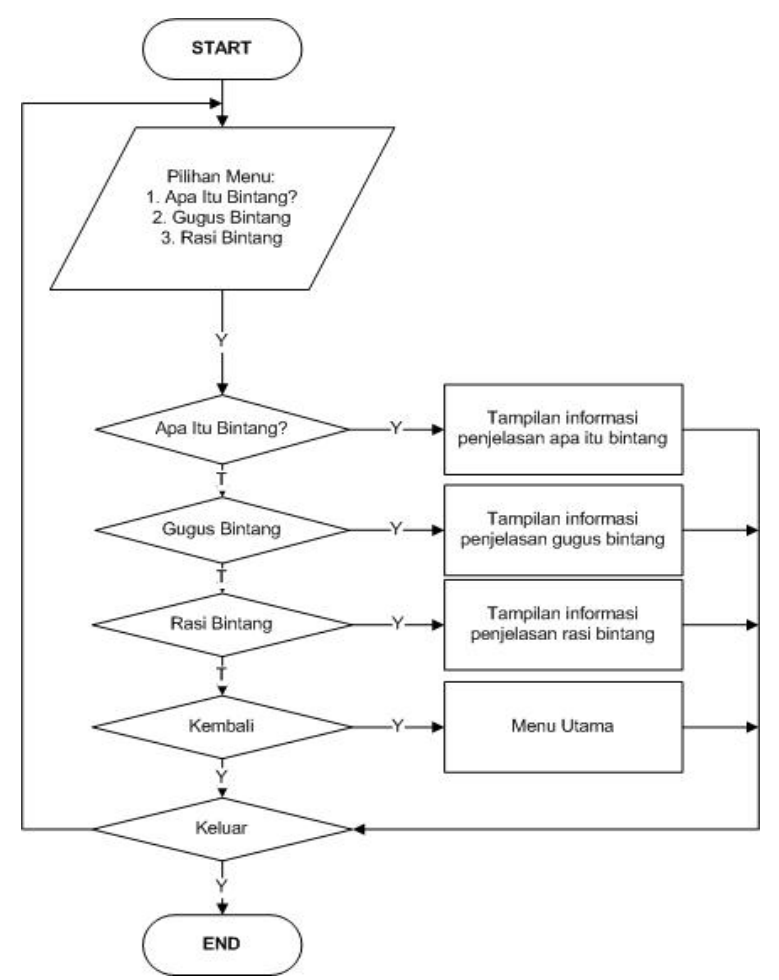

Fig. 5 Stars Flow Chart

5) Astronomy Dictionary Flow Chart
Chart shown in Fig. 6, to describe flowing process in Basic Dictionary of Astronomy, that consist of Search (Cari) Menu and Term List (Daftar Istilah) Menu.

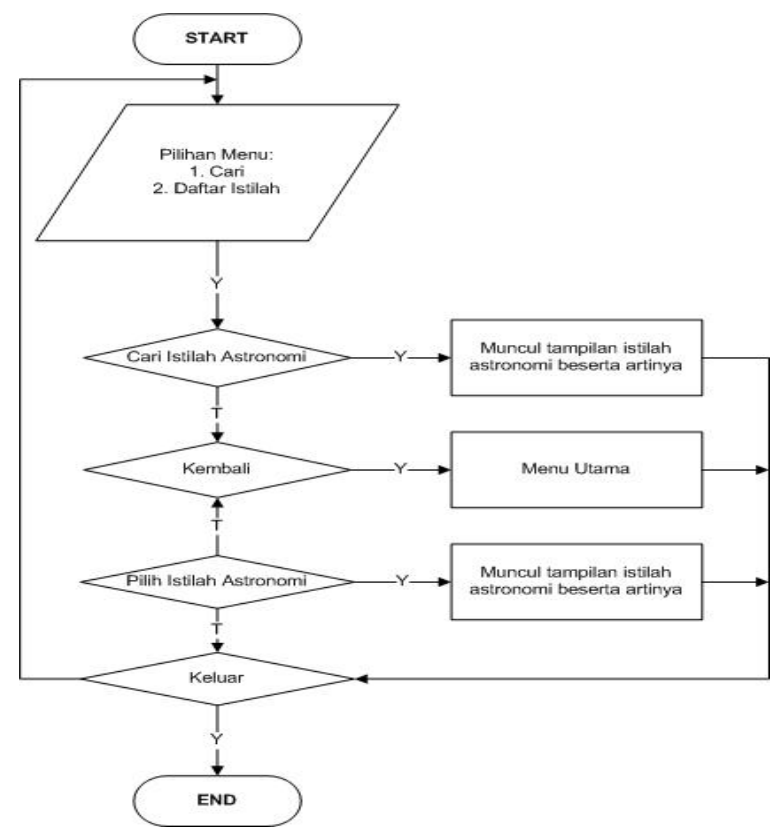

Fig. 6 Astronomy Dictionary Flow Chart

6) Astronomy Quiz Flow Chart

Chart shown in Fig. 7, to describe flowing process in Astronomy Quiz Menu, that consist of Kuis Tata Surya, Kuis Galaksi, and Kuis Bintang

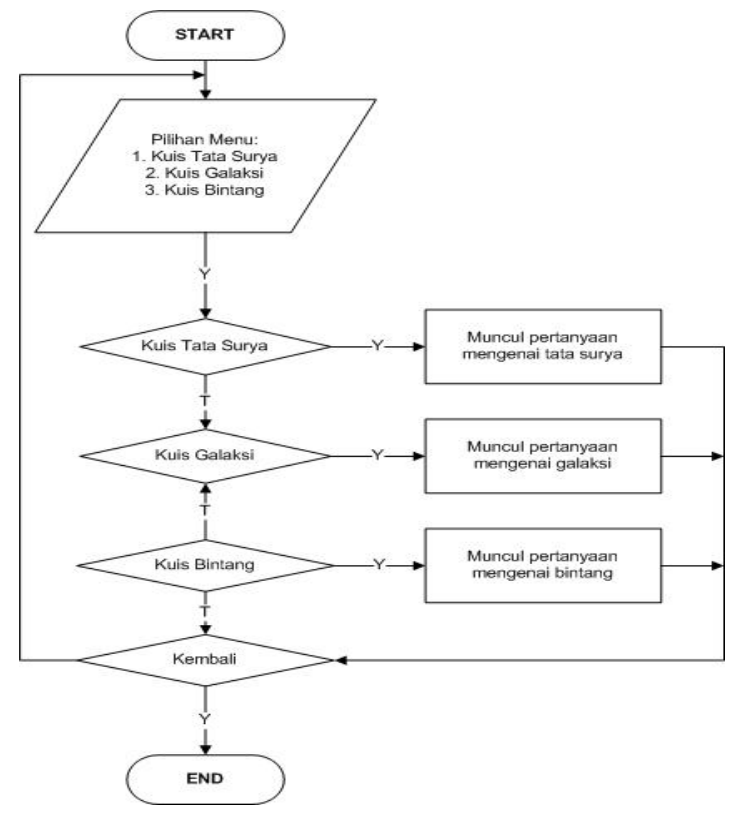

Fig. 7 Astronomy Quiz Flow Chart 


\section{RESULT AND DISCUSSION}

A. Input Spesification Form

\section{1) Main Menu}

The page showing in Fig. 8 show the Main Menu of the application. User can choose five available menus to opened i.e: Tata Surya, Galaksi, Bintang, Kamus Astronomi and Kuis Astronomi

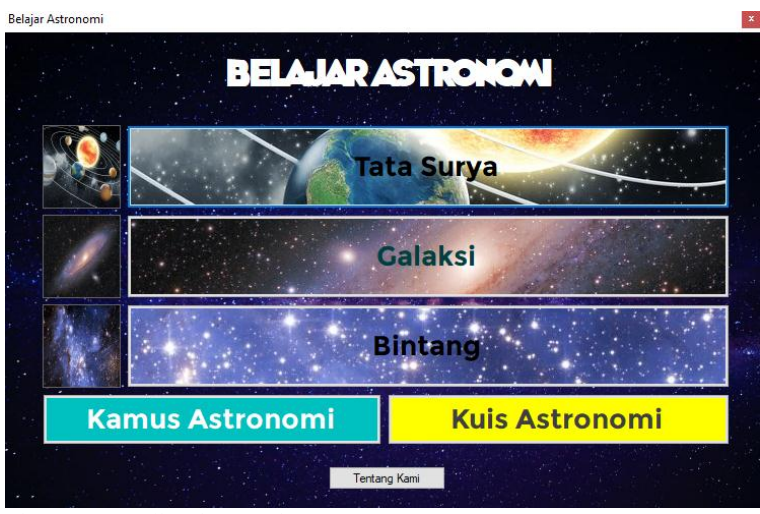

Fig. 8 Application Main Menu

2) Solar System (Tata Surya)

The page showing in Fig. 9 will open if user were choose Tata Surya's menu. It will show the whole image of Solar System where the Sun is a center of the system. Furthermore, user can click any of the image shown, such as Sun (Matahari) or any of the planet. By clicking the image, users could find further information of It.

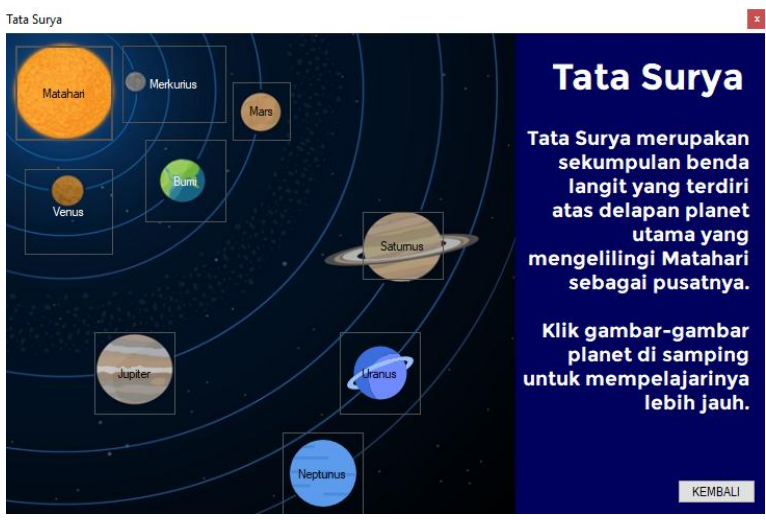

Fig. 9 Solar System (Tata Surya) Menu

3) Galaxy (Galaksi)

The page showing in Fig.10 will open if user were choose Galaksi's menu. It will show the explanation about two kinds of the Galaxies, i.e: Spiral and Ellips. Furthermore, user could click on one of it, then the Information for each kind of Galaxy will shown.

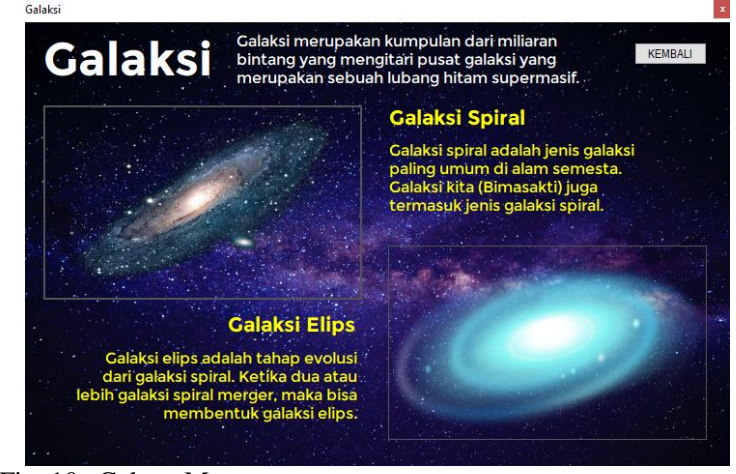

Fig. 10 Galaxy Menu

\section{4) Stars (Bintang)}

The other menu showing in Fig. 11 will open explanation about Stars. This menu will give three further option for detail explanation about the definition of Stars, the Pleiades and the Constellation. Short video about Stars automatically played, if the Bintang's menu opened.

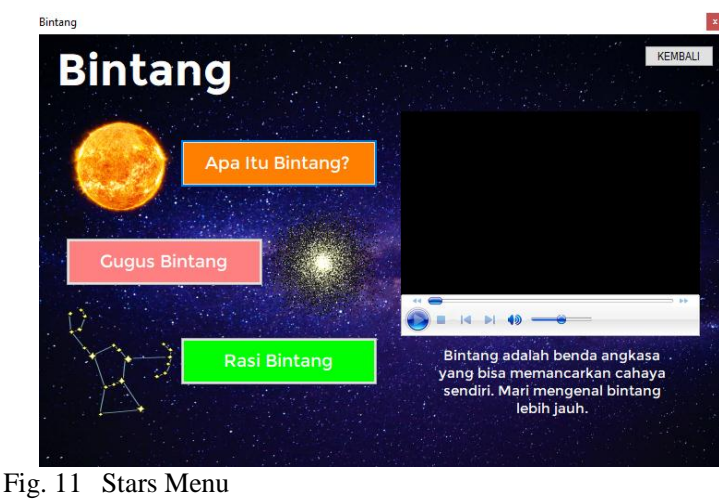

5) Astronomy Dictionary (Kamus Astronomi)

The page showing in Fig. 12 will open, if user were choose Kamus Astronomi. User could search any term of Astronomy.

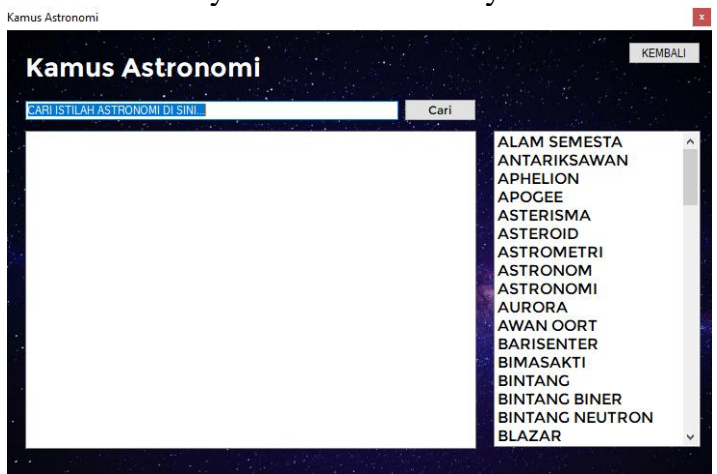

Fig. 12 Astronomy Dictionary

6) Astronomy Quiz (Kuis Astronomi)

The quiz provided in Kuis Astronomi's menu. User will be challenged to test their knowledge about basic of Astronomy through three kind 
of knowledge, i.e: Solar System, Galaxy and Stars. The page shown in Fig. 13.

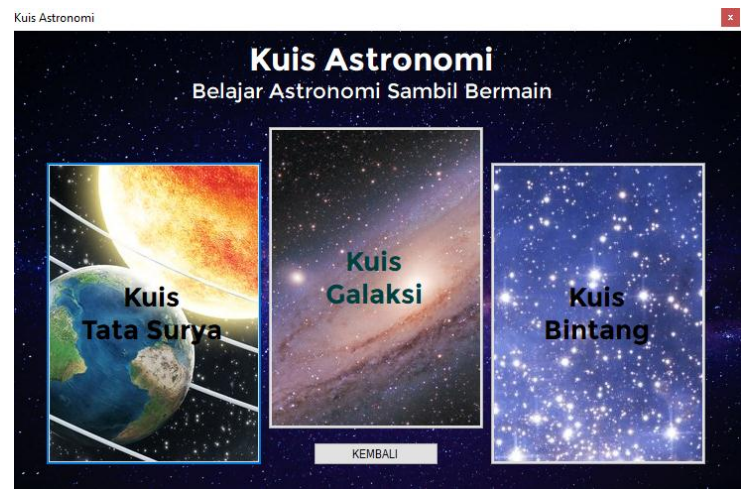

Fig. 13 Astronomy Quiz

\section{B. Output Form Spesification}

\section{1) Sun (Matahari)}

From Solar System menu, user could find further explanation. For example, if user were choose Sun (Matahari), page showing in Fig. 14 will open. Explanation about the subject will added with short video that automatically played.

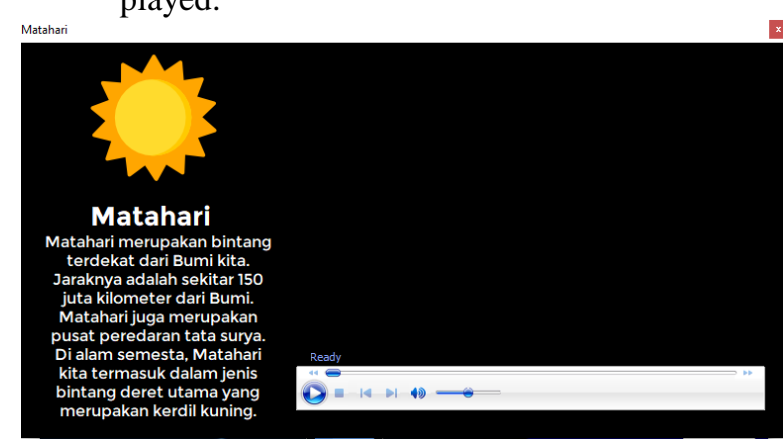

Fig. 14 Further Explanation of the Sun

\section{2) Planets Explanation}

Another example from Solar System menu is show in Fig. 15. In this example, explanation about the Earth will shown and added with a short video.

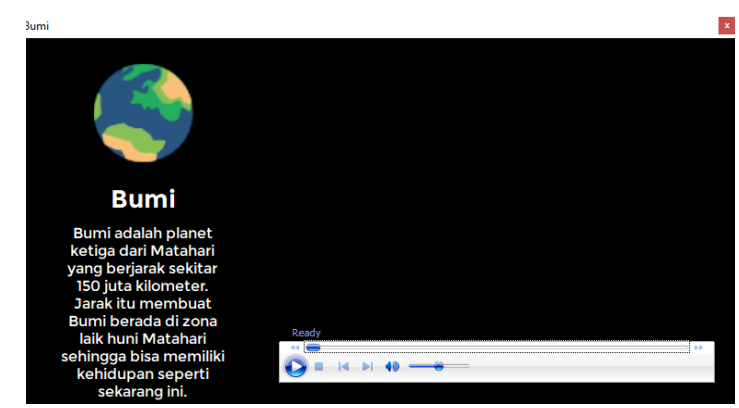

Fig. 15 Further Explanation of the Earth

3) Galaxy Explanation
By choosing one of two kind of Galaxies in the Galaxy Menu, users will see further division of Galaxy, for example Andromeda Galaxy (as seen in Fig. 16).

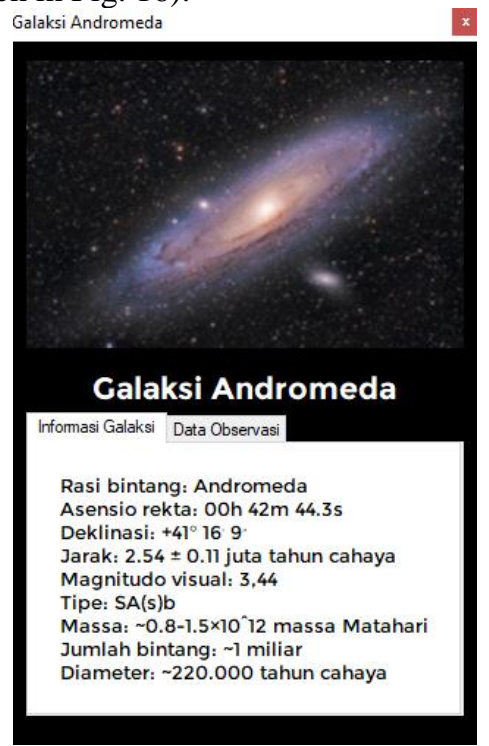

Fig. 16 Galaxy Explanation

\section{4) Stars Explanation}

The other output could see in Fig. 17 which the content is further explanation about the Stars. This menu opened by clicking in one of three options in Stars Menu.

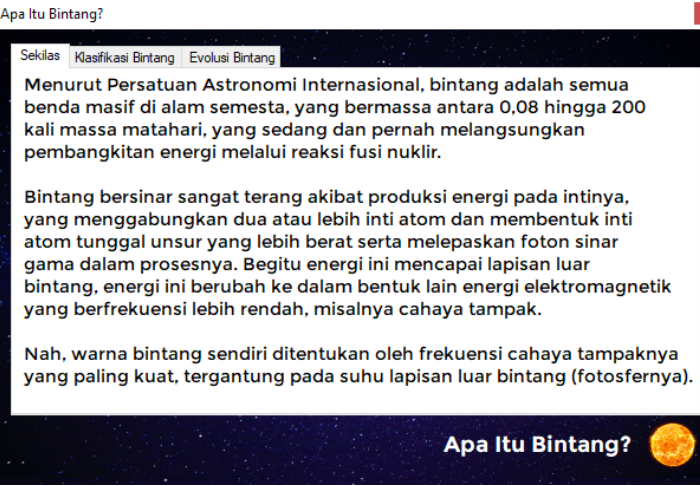

Fig. 17 Stars Explanation

5) Quiz

The last features of the application is created to measure the user ability to understand content of the application. Any question that mention in the Quiz Menu taken from the application itself. Example of quiz page is shown in Fig. 18. 


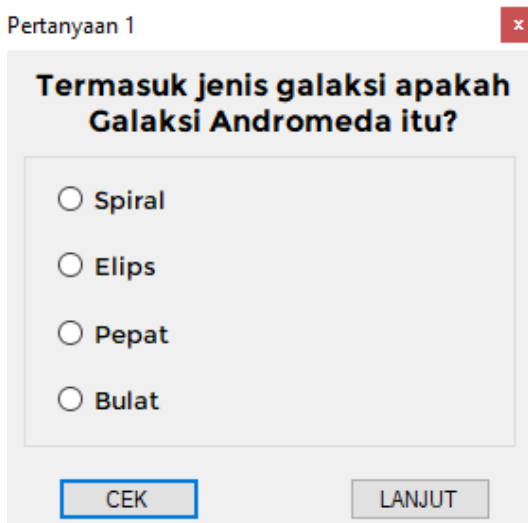

Fig. 18 The Quiz Sample Page

\section{Testing Results}

Belajar Astronomi's application had been tested with black box method before tested by real users. In black box testing, authors tested the application function and features according to requirement analysis. Table 1 shown the test items of application features and the expected results.

TABLE I. TESTING RESULT

\begin{tabular}{|c|l|l|}
\hline No. & \multicolumn{1}{|c|}{ Test Items } & \multicolumn{1}{c|}{ Expected Result } \\
\hline 1 & Application Started & Running smoothly \\
\hline 2 & Main Menu and Sub Menu & $\begin{array}{l}\text { All menus opened } \\
\text { smoothly }\end{array}$ \\
\hline 3 & Short Video & $\begin{array}{l}\text { Automatically Played } \\
\text { when Menu Opened }\end{array}$ \\
\hline 4 & Quiz & $\begin{array}{l}\text { Random Question for Each } \\
\text { Quiz Turn }\end{array}$ \\
\hline 5 & Audio in Video Player & Sound clear and adjustable \\
\hline 6 & Search in Dictionary & $\begin{array}{l}\text { Find desired term or } \\
\text { definition }\end{array}$ \\
\hline 7 & Quiz Answer & Show result true/false \\
\hline 8 & Application Termination & Exit smoothly \\
\hline
\end{tabular}

The users than tested the functionality and features of the application after black box testing. To ensure Its functionality, authors pick 25 respondent that consist of 15 students $(\mathrm{S}), 5$ teachers $(\mathrm{T})$ and 5 parents $(\mathrm{P})$. Users assessment has been summarize in Table II. Users gave answer Yes (Y) or No (N) for each test item which they tried individually on their own computer.

TABLE II. USERS ASSESSMENT

\begin{tabular}{|c|c|c|c|c|c|c|c|c|c|}
\hline \multirow{2}{*}{ No. } & \multirow{2}{*}{ Role } & \multicolumn{10}{|c|}{ Test Item No. } \\
\cline { 3 - 10 } & & 1 & 2 & 3 & 4 & 5 & 6 & 7 & 8 \\
\hline 1 & $\mathrm{~S}$ & $\mathrm{Y}$ & $\mathrm{Y}$ & $\mathrm{Y}$ & $\mathrm{Y}$ & $\mathrm{N}$ & $\mathrm{Y}$ & $\mathrm{Y}$ & $\mathrm{Y}$ \\
\hline 2 & $\mathrm{~S}$ & $\mathrm{Y}$ & $\mathrm{Y}$ & $\mathrm{Y}$ & $\mathrm{Y}$ & $\mathrm{Y}$ & $\mathrm{Y}$ & $\mathrm{Y}$ & $\mathrm{Y}$ \\
\hline 3 & $\mathrm{~S}$ & $\mathrm{Y}$ & $\mathrm{Y}$ & $\mathrm{N}$ & $\mathrm{Y}$ & $\mathrm{Y}$ & $\mathrm{Y}$ & $\mathrm{Y}$ & $\mathrm{Y}$ \\
\hline 4 & $\mathrm{~S}$ & $\mathrm{Y}$ & $\mathrm{Y}$ & $\mathrm{Y}$ & $\mathrm{Y}$ & $\mathrm{Y}$ & $\mathrm{Y}$ & $\mathrm{Y}$ & $\mathrm{Y}$ \\
\hline 5 & $\mathrm{~S}$ & $\mathrm{Y}$ & $\mathrm{Y}$ & $\mathrm{Y}$ & $\mathrm{Y}$ & $\mathrm{Y}$ & $\mathrm{Y}$ & $\mathrm{Y}$ & $\mathrm{Y}$ \\
\hline
\end{tabular}

\begin{tabular}{|c|c|c|c|c|c|c|c|c|c|}
\hline 6 & $\mathrm{~S}$ & $\mathrm{Y}$ & $\mathrm{Y}$ & $\mathrm{Y}$ & $\mathrm{Y}$ & $\mathrm{N}$ & $\mathrm{Y}$ & $\mathrm{Y}$ & $\mathrm{Y}$ \\
\hline 7 & $\mathrm{~S}$ & $\mathrm{Y}$ & $\mathrm{Y}$ & $\mathrm{Y}$ & $\mathrm{Y}$ & $\mathrm{Y}$ & $\mathrm{Y}$ & $\mathrm{Y}$ & $\mathrm{Y}$ \\
\hline 8 & $\mathrm{~S}$ & $\mathrm{Y}$ & $\mathrm{Y}$ & $\mathrm{Y}$ & $\mathrm{Y}$ & $\mathrm{Y}$ & $\mathrm{Y}$ & $\mathrm{Y}$ & $\mathrm{Y}$ \\
\hline 9 & $\mathrm{~S}$ & $\mathrm{Y}$ & $\mathrm{Y}$ & $\mathrm{Y}$ & $\mathrm{Y}$ & $\mathrm{Y}$ & $\mathrm{Y}$ & $\mathrm{Y}$ & $\mathrm{Y}$ \\
\hline 10 & $\mathrm{~S}$ & $\mathrm{Y}$ & $\mathrm{Y}$ & $\mathrm{Y}$ & $\mathrm{Y}$ & $\mathrm{Y}$ & $\mathrm{Y}$ & $\mathrm{Y}$ & $\mathrm{Y}$ \\
\hline 11 & $\mathrm{~S}$ & $\mathrm{Y}$ & $\mathrm{Y}$ & $\mathrm{Y}$ & $\mathrm{Y}$ & $\mathrm{Y}$ & $\mathrm{Y}$ & $\mathrm{Y}$ & $\mathrm{Y}$ \\
\hline 12 & $\mathrm{~S}$ & $\mathrm{Y}$ & $\mathrm{Y}$ & $\mathrm{Y}$ & $\mathrm{Y}$ & $\mathrm{Y}$ & $\mathrm{Y}$ & $\mathrm{Y}$ & $\mathrm{Y}$ \\
\hline 13 & $\mathrm{~S}$ & $\mathrm{Y}$ & $\mathrm{Y}$ & $\mathrm{N}$ & $\mathrm{Y}$ & $\mathrm{Y}$ & $\mathrm{Y}$ & $\mathrm{Y}$ & $\mathrm{Y}$ \\
\hline 14 & $\mathrm{~S}$ & $\mathrm{Y}$ & $\mathrm{Y}$ & $\mathrm{Y}$ & $\mathrm{Y}$ & $\mathrm{Y}$ & $\mathrm{Y}$ & $\mathrm{Y}$ & $\mathrm{Y}$ \\
\hline 15 & $\mathrm{~S}$ & $\mathrm{Y}$ & $\mathrm{Y}$ & $\mathrm{Y}$ & $\mathrm{Y}$ & $\mathrm{Y}$ & $\mathrm{Y}$ & $\mathrm{Y}$ & $\mathrm{Y}$ \\
\hline 16 & $\mathrm{~T}$ & $\mathrm{Y}$ & $\mathrm{Y}$ & $\mathrm{Y}$ & $\mathrm{Y}$ & $\mathrm{Y}$ & $\mathrm{Y}$ & $\mathrm{Y}$ & $\mathrm{Y}$ \\
\hline 17 & $\mathrm{~T}$ & $\mathrm{~N}$ & $\mathrm{Y}$ & $\mathrm{Y}$ & $\mathrm{Y}$ & $\mathrm{Y}$ & $\mathrm{Y}$ & $\mathrm{Y}$ & $\mathrm{Y}$ \\
\hline 18 & $\mathrm{~T}$ & $\mathrm{Y}$ & $\mathrm{Y}$ & $\mathrm{N}$ & $\mathrm{Y}$ & $\mathrm{Y}$ & $\mathrm{Y}$ & $\mathrm{Y}$ & $\mathrm{Y}$ \\
\hline 19 & $\mathrm{~T}$ & $\mathrm{Y}$ & $\mathrm{Y}$ & $\mathrm{Y}$ & $\mathrm{Y}$ & $\mathrm{Y}$ & $\mathrm{Y}$ & $\mathrm{Y}$ & $\mathrm{Y}$ \\
\hline 20 & $\mathrm{~T}$ & $\mathrm{Y}$ & $\mathrm{Y}$ & $\mathrm{Y}$ & $\mathrm{Y}$ & $\mathrm{N}$ & $\mathrm{Y}$ & $\mathrm{Y}$ & $\mathrm{Y}$ \\
\hline 21 & $\mathrm{P}$ & $\mathrm{Y}$ & $\mathrm{Y}$ & $\mathrm{Y}$ & $\mathrm{Y}$ & $\mathrm{Y}$ & $\mathrm{Y}$ & $\mathrm{Y}$ & $\mathrm{Y}$ \\
\hline 22 & $\mathrm{P}$ & $\mathrm{Y}$ & $\mathrm{Y}$ & $\mathrm{Y}$ & $\mathrm{Y}$ & $\mathrm{Y}$ & $\mathrm{Y}$ & $\mathrm{Y}$ & $\mathrm{Y}$ \\
\hline 23 & $\mathrm{P}$ & $\mathrm{Y}$ & $\mathrm{Y}$ & $\mathrm{N}$ & $\mathrm{Y}$ & $\mathrm{Y}$ & $\mathrm{Y}$ & $\mathrm{Y}$ & $\mathrm{Y}$ \\
\hline 24 & $\mathrm{P}$ & $\mathrm{Y}$ & $\mathrm{Y}$ & $\mathrm{Y}$ & $\mathrm{Y}$ & $\mathrm{Y}$ & $\mathrm{Y}$ & $\mathrm{Y}$ & $\mathrm{Y}$ \\
\hline 25 & $\mathrm{P}$ & $\mathrm{Y}$ & $\mathrm{Y}$ & $\mathrm{Y}$ & $\mathrm{Y}$ & $\mathrm{Y}$ & $\mathrm{Y}$ & $\mathrm{Y}$ & $\mathrm{Y}$ \\
\hline
\end{tabular}

Based on the answers, authors summarize the result in a graph as seen on Fig. 19.

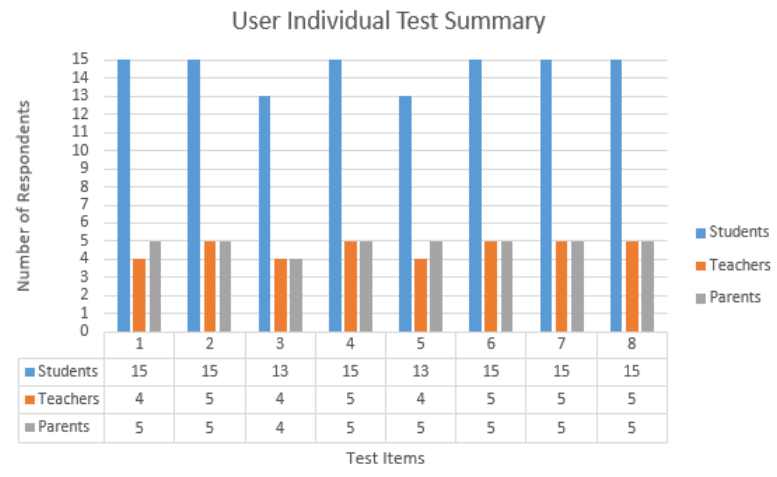

Fig. 19 Summary of User Test

Several test item failure to satisfy during the individual test on the function of the application, but in just few test session. The failure might happened from the user's computer itself. Video and Audio attached into the application depend on the video and audio interface on each computer. So, the problem probably came from the user's computer. Before using the application, users may need to adjust their computer adaptation to audio and video that attached into the application.

\section{CONCLUSION AND SUGGESTION}

Belajar Astronomy's application is a learning application that designed as an added tool in learning process. It could not subsitute the conventional teaching method. Teacher or parent should supervise 
the student along usage of the application to make sure the comprehention of student's understanding about the topics.

To use Belajar Astronomi in computer correctly, students also need to be supervised. They may need help to adjust the application setting, especially for those who less experienced in computer usage.

Further development should delivered in the next research about Learning Application. Learning application must be more interactive in two way interaction. The learning application should be easier to use, comprehensive and flexible.

\section{REFERENCES}

[1] M. B. Younes and S. Al-Zoubi, "The Impact of Technologies on Society: A Review," IOSR J. Humanit. Soc. Sci., vol. 20, no. 2, pp. 82-86, 2015.

[2] P. Sasvari, "The Effects of Technology and Innovation on Society," J. Inf. Commun. Technol., vol. 5, no. 1, pp. 1-10, 2012.

[3] H. Gardner, "Schools Should Adopt ComputerAssisted Education," in Computers and Education, J. D. Torr, Ed. Farmington Hills, MI: Thomson Gale, 2003, p. 12.

[4] J. Li, S. Ma, and L. Ma, "The Study on the Effect of Educational Games for the Development of Students' Logic-Mathematics of Multiple Intelligence," in Physics Procedia: 2012 International Conference on Medical Physics and Biomedical Engineering, 2012, vol. 33, pp. 1749-1752.

[5] V. M. Cojocariu and I. Boghian, "Teaching the Relevance of Game-Based Learning to Preschool and Primary Teachers," in Procedia Social and Behavioral Sciences: CIEA 2014, 2014, vol. 142, pp. 640-646.

[6] H. Johnstone, "Modern Astronomy: An Introduction to Astronomy," School of Physics, The University of Sydney. 2018.

[7] H. Karttunen, P. Kroger, H. Oja, M. Poutanen, and K. J. Donner, Fundamental Astronomy, 5th ed. Heidelberg: Springer, 2007.

[8] R. S. Pressman and B. R. Maxim, Software Engineering: A Practitioner's Approach, 8th ed. New York: Mc-Graw Hill Education, 2015.

[9] Y. Bassil, "A Simulation Model for the Waterfall Software Development Life Cycle," Int. J. Eng. Technol., vol. 2, no. 5, 2012.

[10] D. Singh, A. Thakur, and A. Chaudhary, "A Comparative Study between Waterfall and Incremental Software Development Life Cycle
Model," Int. J. Emerg. Trends Sci. Technol., vol. 2, no. 04, pp. 2202-2208, 2015.

[11] C. Durugbo, A. Tiwari, and J. R. Alcock, "A review of information flow diagrammatic models for product-service systems," Int. J. Adv. Manuf. Technol., vol. 52, no. 9-12, pp. 1193 1208, 2011. 